\title{
Celebrating the 60th anniversary of the Korean Academy of Oral Health
}

\author{
Johng Bai Kim \\ Doctor of Medicine, Honorary President, the Korean Academy of Preventive Dentistry and Oral Health, \\ Honorary Professor, Seoul National University
}

The Korean Empire (1897-1910) was annexed to the Japanese Empire, and the Republic of Korea was founded after the U.S. military administration period. However, Seoul National Dental University could not immediately start teaching and researching oral health and preventive dentistry. In a course called Oral Hygiene, a remnant of Japanese-style education related to oral health and oral disease prevention, course content included types of toothbrushes and the effect of vitamins and hormones on substance metabolism. In 1961, the Korean Academy of Oral Health was founded, and Professor Kim, Ju-Whan was appointed as the first president of the society. Post this, oral hygiene was renamed as preventive dental science, and a preventive dental center was established at Seoul National University in 1966, creating a basic framework for researching the principles and methods of preventing oral health and oral diseases. The following courses were taught: the cause and prevention of dental caries, the development process of water fluoridation, and an topical fluoride application method. Some health centers conducted topical fluoride application projects for elementary school students.

After the Journal of the Korean Academy of Oral Health was first published in 1967, Dr. Kim, Nam-Kyu, who was in charge of public affairs at the Ministry of Health and Social Affairs, and Dr. Park, Kwang-Jin of the National Medical Center, were appointed as presidents for two years each from 1973 to 1977. They continued to hold academic conferences on the development of oral health. I was appointed as the president in 1977 and 1979. Professor Choi, Eu-Gene, Dr. Kim, Hwang-Joong, and Dr. Im, Dong-Woo were appointed as presidents in 1981, 1983, and 1985, respectively. Professor Kim, Chong-Youl was also the president at some point. Various discussions were held to develop oral health and oral health support projects. The society also made efforts to enlist dentists and oral hygienists to public health centers and public health offices. Further, public health dentists were assigned to public health centers across the country, resulting in the disappearance of physicians who were not certified public health dentists. Oral hygienists began being hired in public health centers from 1986.

In 1968, the Korea Associtation for Oral Health was founded, and various oral health education projects, such as an oral health writing award contest, an oral health poster award, and oral health poster, cartoon, and leaflet production and distribution, were conducted. In the first half of the 1970s, the state of public oral health was investigated and reported.

In 1975, Professor Lee, Chung-Suck of Ewha Womans University, Professor Lee, Tae-Won of the National Medical Center, and I participated in the oral health training course hosted by the World Health Organization, inspecting oral health, the oral health support project, and oral health education in Singapore and Malaysia. With Principal Kim Cheon-hwan, Yeonpyeong Middle School, Sangincheon Girls' Middle School, Yeoncheon Middle School, National School for the Deaf, and Changgyeong Elementary School conducted a pilot school oral health project and made every effort to disseminate it throughout the country. A council was convened to discuss the oral health treatment project, oral health treatment system, and oral health treatment manpower supply. In 1981, public schools were encouraged to conduct oral health projects, and government-supplied water fluoridation were carried out in Jinhae and Cheongju. In 1988, the council decided to disperse the water fluoridation for water supplied from the government, a typical oral health support project, to all cities with a population of 50,000 or more. The council further discussed long-term oral health policy 
goals.

The Department of Preventive Dentistry at Seoul National University has conducted the Oral Health Development Symposium every year since the late 1970s. It has consistently insisted that an oral health department be established in the Ministry of Health and Welfare with the intention of specializing oral health administration and developing oral health policies. The plan for the government-supplied water fluoridation was also submitted. The National Oral Health Research Institute was established in 1988. It was then surveyed, and it reported on the state of national oral health in 1990 and laid the groundwork for setting the basic tone for oral health development and long-term oral health policy goals. Evaluation criteria were also established. In 1991, three long-term oral health goals to be achieved during the last decade of the 20th century were established and announced. The Department of Oral Health was established in the Ministry of Health and Welfare in 1997, and the minimum basis for specializing oral health administration was set. And, Korea Occupational Oral Health Institute was also established, and efforts have been made to develop the oral health of workers as part of occupational health. In 1999, the Oral Health Act was enacted, and Department of Oral Health, Ministry of Health and Welfare announced the long-term oral health policy goals to be achieved by 2010 .

Even though our society has made various efforts for the past 60 years since its establishment, public oral health has not yet been sufficiently developed. I believe that our society should continue to lead education and provide guidance so that the governmentsupplied water fluoridation can be fully adopted across the country. Organizations that do not live up to their name, do not deserve to survive. 


\section{대한예방치과 · 구강보건학회 창립60주년을 기념하며..}

김종배

대한예방치과 · 구강보건학회 명예회장 서울대학교 명예교수 의학박사

대한제국이 일본제국에 합방되었다가, 미군정 시기를 거처 대한민국이 건국되었으나, 서울대학교 치과대학에서는 바로 구강보건학과 예방치학을 연구 교수할 수 없었다. 구강보건이나 구강질환예방과 관련되는 일제의 잔재인 구강위생학이라는 교과목에서는 비타민과 호 르몬이 물질대사에 미치는 영향 및 잇솔의 종류가 교수되었었다. 이러한 1961년에 대한구강보건학회가 창립되었고, 김주환 교수가 초대 학회장으로 선임되었다. 그 후 구강위생학이 예방치과학으로 개명되고, 1966년에 예방치과학교실이 서울대학교에 설치됨으로서 구강보 건과 구강질환을 예방하는 원리와 방법을 연구 교수하는 기본적 기틀이 조성되어, 치아우식병의 원인과 예방법 및 불소함량조정관급수식 음의 개발과정과 전문가불소용액도포법이 교수되었으며, 일부 보건소에서 초등학교학생대상 전문가불소용액도포사업을 수행했었다.

1967년에 대한구강보건학회지가 창간된 후, 1973년부터 1977년까지는 보건사회부 치무담당관이었던 김남규 박사와 국립의료원 박 광진 박사를 2년씩 학회장으로 모시고, 소수의 치의사 및 구강위생사와 함께 분기별로 구강보건개발에 관한 학술집담회를 계속했었고, 1977년과 1979년에는 본인이, 1981년에는 최유진 교수가, 1983년에는 김황중 박사가, 1985년에는 임동우 박사가, 1987년 이후에는 김종열 교수 등등이 각각 학회장 직위를 계승하면서, 구강보건과 구강보건지원사업을 개발하려고 다각적인 토론을 거듭했었다. 우리 학회 는 보건소와 보건지소에 치의사와 구강위생사가 충원되게 하는 노력도 해서, 공중보건치의사가 전국 군 보건소에 배치되어 무치의군이 소 멸되었고, 보건지소에도 배치됨으로서 무치의면이 소멸됐으며, 1986년에는 보건소와 보건지소에 구강위생사도 충원되기 시작했었다.

1968년에는 한국구강보건협회가 창립되어, 공모구강보건작문시상 공모구강보건포스터시상 구강보건포스터제작배포를 위시한 구강 보건만화제작배포 구강보건전단제작배포 순회학교구강보건교육 등등의 다양한 구강보건교육사업들이 전개되면서, 1970년대 전반기에 는 국민구강건강실태가 조사 보고되었다.

1975년에는 이화여대 이정석 교수와 국립의료원 이태원 선생과 본인이 세계보건기구가 주관하는 구강보건연수과정에 참여하여, 싱 가포르와 말레이시아에서 구강보건과 구강보건지원사업 및 구강보건교육을 두루 시찰하고 와서, 모방사업을 국내에 확산시키기 시작했 다. 김천환 교장선생과 함께 연평중학교 상인천여자중학교 연천중학교 국립농아학교 국립맹아학교 및 창경국민학교에서 시범학교구강보 건사업을 수행하며, 전국에 확산시키려고 진력했었으며, 보건사회부는 1978년 이후 매년 2회씩 구강보건사업협의회를 소집하여 구강보 건진료사업과 구강보건진료제도 및 구강보건진료인력수급에 관해서 협의하면서, 1981 년에는 국민학교에서 구강보건사업을 수행하게 권 장했었고, 진해시와 청주시에서 관급수불소농도조정사업을 수행하게 했었으며, 1988년에는 협의회가 전형적 구강보건지원사업인 관급 수불소함량조정사업을 인구 5만 이상인 모든 도시로 확산시키기로 결정하고, 장기구강보건정책목표에 관해서도 협의했었다.

서울대학교 예방치학교실에서는 1970년대 말엽부터 매년 구강보건개발심포지엄을 개최하면서, 구강보건행정을 전문화시키고 구강 보건정책을 개발시키려는 의도로 보사부에 구강보건과를 설치해야 한다고 일관되게 역설했고, 진해시와 청주시에서 수행할 관급수불소 농도조정사업의 계획을 직성 제출하였다. 1988년에 국민구강보건연구소를 창설하고, 1990년에 국민구강건강실태를 조사 보고하여, 구 강보건개발의 기본방향과 장기구강보건정책목표를 설정하는 근거를 마련했으며, 구강보건정책집행의 성과를 평가하는 기준도 확보했다. 1991년에는 20세기 최후 10년 동안에 달성할 세 가지 장기구강보건목표를 설정 공표하였고, 정부는 1994년에 국민구강보건연구소가 제 시한 세 가지 목표를 20세기 최후년도까지 달성할 구강보건정책목표로 확정 공표했으며, 1997년에는 보건복지부에 구강보건과가 설치됨 으로서, 구강보건행정이 전문화되는 최소의 기반이 조성되어, 1999년에는 구강보건법이 제정되고, 그 시행령과 시행규칙도 제정 공포되 었다. 1997년에는 한국산업구강보건원도 창립되어, 산업보건의 일환으로 근로자의 구강보건을 발전시키려는 노력도 경주해왔다. 1999 
년에는 보건복지부 구강보건과에서 서기 2010년까지 달성할 장기구강보건정책목표를 공표했었다.

이와 같이 우리 학회가 창립된 이후 60년 동안 다각적이고 다양하게 노력해왔음에도 불구하고, 아직 국민구강보건은 충분히 발전되지 않았다. 관급수불소함량조정사업이 전국에 확산되도록 우리 학회는 계속 선도적으로 교육 지도해야 한다고 본다. 이름값을 못하는 단체는 존속할 가치가 없다고 믿는다.

2021. 9. 